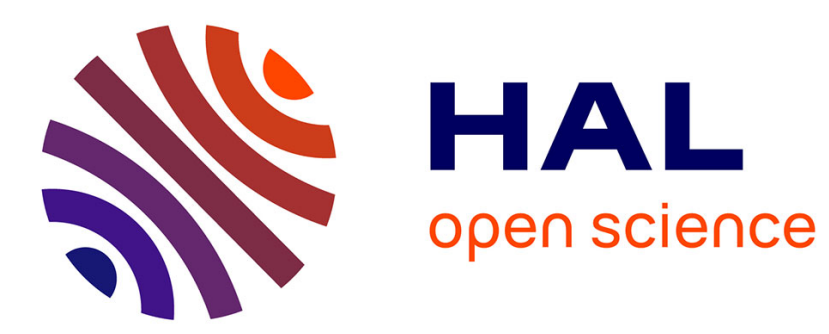

\title{
The alkali soils of the middle Niger Valley Origins, formation and present evolution
}

Laurent Barbiero, Brigitte van Vliet-Lanoë

\section{To cite this version:}

Laurent Barbiero, Brigitte van Vliet-Lanoë. The alkali soils of the middle Niger Valley Origins, formation and present evolution. Geoderma, 1997, 84, pp.323-343. hal-00364728

\section{HAL Id: hal-00364728 \\ https://hal.science/hal-00364728}

Submitted on 26 Feb 2009

HAL is a multi-disciplinary open access archive for the deposit and dissemination of scientific research documents, whether they are published or not. The documents may come from teaching and research institutions in France or abroad, or from public or private research centers.
L'archive ouverte pluridisciplinaire HAL, est destinée au dépôt et à la diffusion de documents scientifiques de niveau recherche, publiés ou non, émanant des établissements d'enseignement et de recherche français ou étrangers, des laboratoires publics ou privés. 


\title{
The alkali soils of the middle Niger Valley Origins, formation and present evolution
}

\author{
Laurent Barbiéro $^{1,2}$ and Brigitte Van Vliet-Lanoe ${ }^{3}$ \\ 1 - ORSTOM, BP 1386, Dakar, Sénégal. (barbiero@dakar.orstom.sn)_correspondence \\ 2 - INRA-ENSA, Unité de Science du sol et bioclimatologie, 65 rue de St Brieuc, 35042 Rennes Cedex, France \\ 3 - Sédimento-Géosciences, Université de Rennes I, 35042 Rennes Cedex, France. (Lanoe@univ-rennesl.fr)
}

\begin{abstract}
:
In Niger Republic, the regional development of irrigation along the river Niger is confronted with an large extension of alkali soils. The study of one of these areas, on the Liptako bedrock, reveals a concentric soil distribution: in a zone of brown soil with abrupt textural change and alkaline in depth (stagnic Solonetz), appears a ring of brown steppe soils (cambic Calcisol), and zones of alkali soils (Solonetz). These alkali soils are not saline but their soil solution is more concentrated than in brown steppe soils. The study of the abrupt contact between brown steppe soils and alkali soils shows morphological and geochemical changes, due to calcite and fluorite precipitation.

The detailed study of this contact demonstrates a present transformation of alkali soils into brown steppe soils. Therefore, it appears that soil alkalization is no longer in process on the terraces of the river Niger. The formation of brown steppe soils and alkali soils may be explained by the existence of a former pond. This hypothesis is supported by aerial pictures and microscopic observations. It is also consistent with a recent study of the hydrology of sahelian ponds and with considerations on the chemical quality of the runoff.
\end{abstract}

Key words: non-saline alkali soils/sodic soils, soil genesis, de-alkalization, Sahel, Niger.

\section{Introduction}

In the semi arid area of the middle Niger valley (Niger Republic), irrigation techniques had been developed to respond to aridity and increasing population (fig. 1). Initially, the agricultural practices most suitable for the region have been tested on a few trial areas. Often, the main threat to sustainable agriculture is the reduced fertility associated to alkali soils existing prior to irrigation. Bozza and Boyer (1988) observed that up to $70 \%$ of the area of some irrigated perimeters were covered by non saline alkali soils.

These alkali soils develop always in contact with the non alkaline brown steppe soils (Barbiéro and Berrier, 1994). The contact between the two soil types is always so abrupt that in the all West-Africa surveys, this two units were represented as associated soil unit (Gavaud, 1977; Maignien, 1965). Such soil distribution has been observed along the river Falémé in Sénégal (Chauvel, 1966) and also in semi-arid Pakistan (Choudhri, 1972). However, this pattern differs clearly from what exists in the Niger valley in Mali, where a shallow water table is responsible for present alkalization (N'Diaye, 1987, Valles et al., 1989a, Bertrand et al., 1993, 1994).

This specific distribution of soil units observed in the Niger valley in Niger Republic leads to the question of their origin; it is the first objective of this paper. The main difference between the two soil types (alkali soil and brown steppe soil) is the soil solution being more concentrated in alkali soils although alkali soils are non-saline. Therefore, two hypothesis are proposed to explain soils genesis: (i) soil alkalization is induced by the concentration by evaporation of accumulated dilute solutions; (ii) the absence of soil alkalization where brown steppe soils are observed result from localised percolation of dilute water. 
The second objective of this paper is to explain the present evolution of alkali soils, i.e., does the alkalization, corresponding to such distribution of soil units, progress or regress, which is essential for a sound management of irrigation in these areas using local waters.

\section{Materials and Methods}

The study was located at «Lossa»-Niger $\left(13^{\circ} 54 \mathrm{~N} 1^{\circ} 35 \mathrm{E}\right)$ in the 90 ha domain under irrigation (fig. l). This irrigated area lies at the bottom of a small $10 \mathrm{~km}^{2}$-catchment on the left side of the river Niger. The northern part of the domain (15 ha) was survied in detail (fig. 2).

The climate belongs to the type III semi-arid of the African zonation (Griffiths, 1972), with a short rainy season from June to September $(400 \mathrm{~mm}$ rainfall). The annual potential evapotranspiration is $2400 \mathrm{~mm}$. During the 8 months of the dry season, dry winds are blowing from the northeast. The mean annual temperature is about $33^{\circ} \mathrm{C}$ with maximum around $47^{\circ} \mathrm{C}$ recorded. The water table located at 30 to 40 meters deep is not subject to evaporation process.

The soil has a sandy clay texture and develops from an alkaline gneiss with biotite. This parental material, locally call «Liptako bedrock», is part of the regional Birrimian substract. The regolith (i.e. weathered parental material) of this crystaline bedrock appears between 1 and 1.2 metre depth. Preliminary studies of the whole catchment shown three major differenciations in the sandy clay soil properties (Barbiéro, 1995): 1 - a non-saline alkali soil $\left(\mathrm{pH}_{\mathrm{s}}=8.5\right.$ to $9.8(\mathrm{~s}=$ on saturated paste), $\mathrm{EC}_{\mathrm{s}}=0.22$ to $0.32 \mathrm{dSm}^{-1}$, S.A.R. $=12$ to $28\left(\mathrm{mmolL}^{-1}\right)^{1 / 2}$, E.S.P. $=5$ to $\left.40 \%\right) ; 2-$ a non-alkaline brown steppe soil $\left(\mathrm{pH}_{\mathrm{s}}<8.4, \mathrm{EC}_{\mathrm{s}}=0.07\right.$ to $0.22 \mathrm{dSm}^{-1}$, E.S.P. $=0.5$ to $2 \%$ ), which is much more fertile; 3 - a brown soil with abrupt textural change alkaline in depth (in depth: $\mathrm{pH}_{\mathrm{s}}=$ 9.1 to $9.3, \mathrm{EC}_{\mathrm{s}}=0.15$ to $0.25 \mathrm{dSm}^{-1}$ )

\subsection{Soil survey}

A detailed soil $\mathrm{pH}$ survey of the 15 ha north of the irrigated domain was conducted on a 10 metre squared grid. Soil were collected with an auger at a depth of $40 \mathrm{~cm}$. PH value was measured in the laboratory on saturated pastes. Soil morphology was observed and described in 18 pits inside and outside the irrigated area (fig. 2). PH datas combined with morphological observations were used to delimit the soil units. Two soil types were observed in the 15 ha irrigated area: the nonsaline alkali soil and the non-alkaline brown steppe soil. Evidence of brown soil with abrupt textural change alkaline in depth was found at the limit of the area. Therefore, the survey was extended outside the irrigated area to cover all the catchment bottom and to understand the soil distribution.

An aerial picture of the catchment was used to complete the observations (I.G.N., 1975, phot. 4).

\subsection{Morphology and geochemistry}

A $7 \mathrm{~m}$ length and $1.2 \mathrm{~m}$ deep trench was dug across an abrupt contact between brown steppe soils and alkali soils (fig. 2) localised by the soil survey. The trench have been show to be chemically and morphologically representative of the two soil types characteristics. The pedological layers were identified, described and sampled for laboratory characterisation and geochemistry (fig. $3)$. Air dry soil block were impregnated with a polyesther resin and vertical thin sections $(70 \times 110$ $\mathrm{mm}$ ) were made and described according to Brewer (1976). Precipitation forms of the calcite in calcareous concretions were observed using a SEM (XL 20 Philips at $15 \mathrm{kV}$ ) with a LINK Analytical eXL energy dispersive X-Ray system.

Over one face of the trench, in situ $\mathrm{pH}$ values were measured (on saturated paste) on a regular grid $(0.1 \mathrm{~m}$ deep $\times 0.2 \mathrm{~m}$ wide $)$ to locate in detail the variation of geochimical characteristics. To define and measure the general geochemical soil characteristics along the trench, 72 soil samples were also taken according to a coarser regular grid $(0.1 \mathrm{~m}$ deep x $0.95 \mathrm{~m}$ wide , fig 3). Saturated paste extract were analysed by ion chromatography (Dionex). The quantified elements were : $\mathrm{Na}^{+}, \mathrm{K}^{+}, \mathrm{Ca}^{++}, \mathrm{Mg}^{++}, \mathrm{NH}_{4}^{+}, \mathrm{Cl}^{-}, \mathrm{SO}_{4}^{--}, \mathrm{F}^{-}, \mathrm{NO}_{3}^{-}, \mathrm{NO}_{2}^{-}, \mathrm{PO}_{4}^{---}$, acetates, formates and oxalates. To distinguish and quantify fluoride from small organic anions (acetates and formates) a second 
analysis was performed using the sodium tetraborate as eluant. Althrough, sample volumes were too small for titration of the Carbonate alkalinity (i.e., $\left(\mathrm{HCO}_{3}{ }^{-}\right)+\left(\mathrm{CO}_{3}{ }^{2-}\right)$ ), which constitues the major anionic compound, its value was derived from the ionic balance of the solution. An acid titration (Gran method, 1952) was performed on three samples giving similar results as the estimation by the ion balance. Silica was quantified by colorimetry (Na-molybdate method at $\mathrm{pH} 1.6$ (Charlot, 1961)). Equilibrium's computations were performed using the «Aqua »software package (Vallès and De Cockeborne, 1992), derived from the «Gypsol » model (Vallès and Bourgeat, 1988).

Using the same procedure, an analysis of the geochemical content of surface runoff water was undergone. Runoff water was collected on the upslope of the studied area after rain in four different puddles. The chemical quality of the runoff water, regarding the risk of alkalization, was estimated using the concept developed by Vallès et al. (1991).

\section{Results}

\section{1 soil distribution in the landscape}

Figure 2 show the extension of the three soil units in the studied area. Three « concentric domains » are delimited:

- In the centre of the area, a large zone ( $3 \mathrm{ha}$ ) of high $\mathrm{pH}$-values ( $>8.5$ ) is observed. Smaller alkaline zones are also found. The increase of $\mathrm{pH}$-values is abrupt at the edge of these zones. They correspond to alkali soils. Due to its prismatic structure and natric horizon, this soil belong to Solonetz.

- These alkaline zones are surrounded by a larger area where $\mathrm{pH}$-values range from 7 to 7.5 . It corresponds to non alkaline brown steppe soils (cambic Calcisol).

In the outermost part of this area, another domain of high pH-values (7.5 to 8.5) in contact with the non alkaline brown steppe soils was found. However the transition between this domains is progressive. This large zone correspond to brown soil with abrupt textural change, alkaline in depth. This third soil unit observed correspond to the stagnic Solonetz.

\subsection{Soil morphology}

Figure 3 present the soil transect along the $7 \mathrm{~m}$ trench in the transition zone (fig. 2). The alkali soil are located on the left end of the trench and the brown steppe soil in the right end. The alkali soil show a shallow grey (10YR6/1) sandy and coherent superficial horizon (around $0.05 \mathrm{~m}$ ) overlying a grey (10YR5/2) sandy clay and hardly coherent material (around $70 \mathrm{~cm}$ depth) with a large prismatic structure (from 0.5 to $1.2 \mathrm{~m}$ wide) and a massive substructure (fig. 4 ). The weathered bedrock below this prismatic layer presents various lime $\left(\mathrm{CaCO}_{3}\right)$ patterns: nodules, soft powdery volumes of 0.05 to $0.10 \mathrm{~m}$, and $\mathrm{CaCO}_{3}$ pseudo-mycelia. The calcareous nodules present a white indurated cortex and a grey compact centre (fig. 5a). These nodules are solid and impossible to break under finger pressure. The calcite crystals in the nodules do not present any corrosion patterns (phot. 1). The weathered bedrock with undisturbed petrographic structure appears near $1 \mathrm{~m}$ deep.

Althought, the brown steppe soils had a similar soil texture as the alkali soil, large differences in the soil structure are observed. The superficial sandy horizon is generally thicker. It overlies a brown (10YR5/5) sandy clayed horizon with prismatic structure $(0.1 \mathrm{~m})$ and cubic substructure (cubes ranging from 0.01 to $0.02 \mathrm{~m}$ not represented in fig. 3). The weathered bedrock presents fewer calcareous precipitates than in the alkali soil. They include friable nodules, soft powdery volumes (from 0.02 to $0.05 \mathrm{~m}$ ) and pseudomycelia veiling. These calcareous nodules are very fragile (fig. 5b). A remaining cortex is observed and the centre of the nodule is generally composed of soft powdery calcite. The calcite precipitates as irregular spherules (phot. 2), sometimes rhomboid as those observed by Bouzigue et al. (1992) in a vertisol of Cuba. The weathered bedrock with undisturbed petrographic structure also appears near $1 \mathrm{~m}$ deep.

In the brown soil with abrupt textural change, alkaline in depth, the superficial sandy horizon is $0.25 \mathrm{~m}$ thick. Its color is 10YR6/2 and locally bleached (10 YR7/1) in the lower part of the 
horizon. An abrupt horizontal and regular transition leads to a brown (10YR5/4 to 5/5) sandy clay horizon, 0.3 to $0.4 \mathrm{~m}$ thick with subangular polyedric structure. Near $0.6 \mathrm{~m}$ depth, a significant change is observed in the color (10 YR5/2), in the structure (massive) and in the cohesion (hardly coherent). The weathered bedrock appears at $0.9 \mathrm{~m}$ depth, including lime: nodules and pseudomycelia veiling. The weathered bedrock with conserved petrographic structure appears near $1.1 \mathrm{~m}$ deep.

Thin section observations under an optic microscope of the alkali soils and brown steppe soils reveal many microscopical structures of pond organisms: i.e. sponges spicules, diatoms, cyanophyceae shells. These structures do not appear in brown soils with abrupt textural change, alkaline at depth.

\subsection{Chemistry of alkali soils and brown steppe soils.}

The soil solutions show distinct chemical facies, from a calcic bicarbonate type in the brown steppe soil to a sodic bicarbonate type in alkali soil. The changes in the chemical facies along the $7 \mathrm{~m}$ length trench are presented in fig. 6 and 8. A similar behaviour of sodium, fluoride, carbonate, alkalinity and T.D.S. is observed, opposite to the behaviour of calcium and magnesium. Fluoride concentration are particularly high and were found to be a major component (fig. 6d).

The chemical analysis data were sorted according to their sodium amount and presented in concentration diagrams (fig. 7). In these diagrams, the concentration factor is defined as $\mathrm{CF}=[\mathrm{Na}] /$ $[\mathrm{Na}]_{0}$ where [ ] denote molality and $[\mathrm{Na}]_{0}$ refers the lower $\mathrm{Na}$ molality at the origin of the concentration diagram.

Soil solutions are more concentrated in alkali soils than in brown steppe soil. Fluoride amount and carbonate alkalinity increase consistently but less rapidly than sodium concentration; calcium, magnesium and potassium amount decrease. An initial approximately constant silica molality is followed by an increase at elevated concentration factors. The $\mathrm{pH}$-value of soil solution increases with sodium concentration. Chloride and sulfate varie similarly. However, their amounts are low, their relation with sodium is more scattered and they do not present a particular repartition along the large pit.

\subsection{Morphological and geochemical transition between alkali soils and brown steppe soils}

The bedrock does not show any lateral variations of facies in the $7 \mathrm{~m}$ lenght trench. The morphological transition between the alkali soil and the brown steppe soil is highlighted by a latteral change in the grey (10YR5/2) sandy clayed matrix of the alkali soil. Centimetric brown (10YR5/5) volumes appear progressively in the matrix and become predominant at $\mathrm{x}=4 \mathrm{~m}$ in fig. 3 . This defines the morphological transition between the two soil types. The changes from a wide prismatic massive structure to a finer prismatic cubic structure indicate a transition in the same place.

Close to this transition, the strength of the calcareous nodules is intermediate between the two former descriptions (fig. 5c). They can be crushed on a knife blade. Two types of calcite precipitates are observed in these nodules. Crystals of calcite similar to those described in the alkali soil are observed, though with many dissolution patterns (phot. 3). Such dissolution patterns of the calcite in basic solutions were described by Delmas et al. (1987). Calcite similar to the spherules observed in the brown steppe soils are also found in the same nodules.

The geochemical transition can be located using the distribution of Total Dissolved Substances (T.D.S.) of the saturated paste extracts (fig. 8). This geochemical transition is offset of 1 $\mathrm{m}$ to the left, compared to the morphological transition (fig. 9).

\subsection{Quality of the Runoff waters}

The chemical analysis of the runoff waters are reported in the table I. The runoff waters are very dilute (T.D.S. ranges from 1.2 to 4.8 meq. L $^{-1}$ ) but present a positive Calcite Residual Alkalinity $\left(\mathrm{ARG}_{\text {calcite }}=\right.$ Alkalinity $-(\mathrm{Ca})$ ) ranges from +0.4 to +1.1 meq. $\mathrm{L}^{-1}$ (Van Beek and Van Breemen, 
1973) and therefore belong to the carbonate alkaline familiy (Valles et al., 1991). Such waters evolve in a carbonate alkaline way by concentration.

\section{IV discussion}

The geochemical data suggest that carbonated alkalinity an fluoride are controlled by a geochemical process. Calcium and magnesium are also clearly controlled. Calcite precipitate are observed in alkali soil and brown steppe soil and the equilibrium with respect to calcite is reached. Moreover, fig. 10 shows that the soil solutions are also in equilibrium with respect to fluorite $\left(\mathrm{CaF}_{2}\right)$ in the alkali soil. The precipitation of fluorite in the alkali soil is concomitant with that of calcite, although the presence of fluorite could not be verified by XRD due to its low contents. Calcite and fluorite precipitation explains the major change in the chemical facies between brown steppe soils and alkali soils. Calcite precipitation is an usual mechanism in alkalization processes. However, fluorite precipitation, well known in saline alkali soils or alkaline brines (Darragi et al., 1983, Gueddari, 1984, Chernet and Travi, 1993) and suspected by Jacks and Sharma (1995) in south India, has never been reported in non saline alkali soils (Barbiéro et al., 1995). It amplifies the geochemical control of calcium which is initiated by the calcite formation. Microanalysis conducted on the calcareous precipitates indicate a $\mathrm{Mg}^{2+}$ content of $2 \%$ in the calcite. This phenomenum cannot explain the control of $\mathrm{Mg}^{2+}$ observed in the soil solutions. Magnesian silicate formation occurs probably simultaneously (Barbiéro, 1995, Marlet et al., 1996) as observed in other sahelian regions such as Mali (Valles et al., 1989b) and Chad (Gac et al., 1977). All these precipitations use up the bivalent cations and induce a significant increase in the Sodium Adsorption Ratio (S.A.R.).

The alkaline and sodic environment induces clay dispersion, decrease in aggregate stability and an important decrease of soil hydraulic conductivity. The soil becomes very compact and the resistance to penetration increases drastically. A very hard crust appears at the soil surface after rainfall (Barbiéro, 1995). These physical consequences of alkalization are a well-known phenomena (Sheinberg and Letey, 1984; Abu Sharar et al., 1987; Sumner, 1993).

\section{Origin of the soil geochemistry.}

The main difference between the two soil types is the soil solution being more concentrated in alkali soils which result in the precipitation of calcite and fluorite. Therefore, two hypothesis are proposed to explain soils genesis: (i) soil alkalization is induced by the concentration by evaporation of accumulated solutions; (ii) the absence of soil alkalization where brown steppe soils are observed results from localised percolation of dilute water.

None of this hypothesis is exclusive; the two mechanismes can occurs at the same time depending of hydrological regime zonal distribution. Indication of the former hydrological environment that will explain the soil formation was researched in the present features of the studied area.

The soil units show a concentric distribution. On the aerial picture (phot. 4), structures associated with former pond limits are observed in the valley bottom, in the presently irrigated area of «Lossa». The limits of the pond outlined in phot. 4, and that intersect successively, show clearly that former pond had moved several time southwards. The formation of this pond is explained by the presence of the dune and the sandy bank of the river Niger blocking the runoff of water northward and north-westward. Nowadays, the bank is discontinuous and the catchment is open on the Niger alluvial valley.

Indices of this former endoreic behaviours of the «Lossa» catchment are found in the soil. The numerous structures of aquatic microscopical organisms, observed in alkali soils and brown steppe soils support the existence of an old pond on top of the two soils.

The water in the former pond originates from local runoff. The runoff water collected up slopes from the site show ambiguous chemical characteristics. They are dilute waters, undersaturated with respect to calcite, fluorite and magnesian silicate. Such water can leach soluble salts of the soil by percolation. However, their alkalinity is higher than their calcium amount. They 
evolve in an carbonate alkaline way by concentration if they evaporate (Van Beek and Van Breemen, 1973, Cheverry, 1974, Droubi et al., 1980, Valles et al., 1991). The fate of soil in contact with this type of solution depends on the balance between evaporation and percolation.

The zonation of two constrasted hydrological regimes had been described by Desconnet (1994) in actual sahelian ponds. During and after rainfall, the pond fills up with runoff up to a « high level». When the water supply stops, a consequent drainage is observed down to a «low level». From then on, the drainage is blocked and the remaining water only evaporates. The shift from a drainage to an evaporation process is associate to the presence of a clay carpet in the center of the pond, that reduces considerably infiltration.

All these observations and remarks match and allow to put forth a model of soil genesis in the study area (fig. 11). Initially the catchment bottom was probably cover by brown soil, alkaline in depth resulting from the bedrock weathering in semiarid conditions. Alkali soils and brown steppe soils proceed from two contrasted hydrological regimes in an old pond, supplied by dilute but alkalinizing runoff water. The percolation of the water between the high and the low level of the pond has probably transformed the brown soil alkaline in depth into brown steppe soil. In constrast, evaporation and concentration of water under the low level intensified alkalization and led to alkali soils in the centre of the pond.

\section{Present evolution of the soil.}

The endoreic feature explains the soil origin by redistribution of alkalization in the valley bottom. Nowadays, since the pond has disappeared, the present dynamic of these two soil units has to be considered. The contact between brown steppe soil and alkali soil is abrupt and shows a significant inclination from the vertical (fig. 3). Such contact between two very contrasted soil units, from a chemical and morphological point of view, appears like a lateral transformation. The inclination of the contact suggests a transformation of alkali soil into brown steppe soil if the evolution is downwards (Fritsch et al., 1992). However, it suggests an alkalization if the transformation is upwards under the influence of evaporation. Small grey volumes are observed in the brown matrix and brown volumes are observed in the grey matrix. These volumes can be interpreted as precursors or as remnants; they do not give any information about the direction of the transformation. A decisive hint is provided by the structure and aspect of calcareous nodules (fig. 5 $a, b, c$; phot. 1, 2 and 3). The nodules are compact and stable in the alkali soil, composed of calcite and quartz. The cortex is continuous. They are weakened near the contact zone and disappear in the brown steppe soil. The remaining cortex which is observed in the brown steppe soil is discontinuous, does not correspond to a structure in formation, and indicates a degradation of these nodules along the trench. The nodules can only be formed in the alkaline environment and are destroyed when the grey matrix of alkali soil is invaded by brown matrix of brown steppe soils. The disaggregation of the nodules is confirmed by the dissolution patterns of calcite observed near the transition zone. Intact nodules being attributed to alkali soils, this dynamic of the calcite shows a regression of alkali soils.

The detailed study of the contact demonstrates a natural transformation of alkali soils into brown steppe soils. The gap of 1 meter (fig. 9) observed between morphological transition (changes in colour, structure, compactness, fig. 3 and 4) and geochemical transition (increase in the TDS on the «saturated paste extract», fig. 8) shows that the alkali soil lost its geochemical properties before acquiring the morphology of brown steppe soils. This gap shows that the transformation is in process.

The transformation generates an abrupt boundary between alkaline and brown steppe soils. It probably results from a "funnel effect" due to the hydrodynamic properties of the soils. At each rainfall, the water runs over the surface of the alkali soil, which is hardly permeable. It percolates through the more permeable brown steppe soil (Barbiéro, 1995). 
The boundary between brown steppe soils and brown soils with a abrupt textural change is more diffuse because this zone is located on the edge of the old pond and was rapidly dried off after the rain, and the amount of percolated water is low.

\section{Conclusion}

Brown steppe soil and alkali soils are two associated soil units frequently observed in the West-African Sahelian zone. One of this association was studied here in the middle valley of the river Niger (in Niger Republic) to understand the origins and the present evolution of alkali soils.

The soil distribution probably results from a former pond which induced brown steppe soils and alkali soils by zonation of two contrasted hydrological regimes. From a geochemical point of view, alkalization is caused by concentration of the soil solution, which evolves in an carbonate alkaline way, and by precipitation of calcite, fluorite and probably magnesian silicates. The studied area of «Lossa» appears representative of the regional soil alkalization. Soil units distribution and geochemical processes similar to the «Lossa» site were observed in other sites, even on alluvial deposits downslope (for example «Sona» (1358N 1³4E), Guero, 1987; Bozza and Boyer, 1988; Valet, 1995). Nevertheless, pond inducing alkaline features in soils can not be generalised to the whole Sahelian zone. More often, the development of acid gley is observed below sahelian pond (Gavaud, 1977). Such difference are probably due to opposite water quality and drainage conditions. The studied case differs from the interior delta in Mali, where a shallow water table is observed and where alkalization is in process (N'Diaye, 1987, Bertrand et al., 1993, 1994).

The «Lossa » catchment is presently opened on the alluvial valley of the river Niger and the soils are no longer in equilibrium with the local environmental conditions. The transformation of alkali soils into brown steppe soil expresses an evolution towards a new equilibrium. This natural evolution opens up the possibility of accelerating de-alkalization of certains areas suitable for agriculture. This natural de-alkalization, fast at a soil formation time scale, was furthered to improve the soils by proper management of irrigation and crop (Barbiéro et al., 1995, 1997). However, in spite of the natural trend towards de-alkalization, the irrigation with water of the river Niger may well lead to secondary alkalization. The restoration of a chemical environment favouring a stable structure, is necessary for a long lasting improvement of alkali soils.

\section{References}

Abu Sharar TM, Bingham FT, and Rhoades JD, 1987 Reduction in hydraulic conductivity in relation to clay dispersion and disaggregation. Soil Sci. Soc. Am. J., 51: 342-346.

Barbiéro L, 1995 Les sols alcalinisés sur socle dans la vallée du fleuve Niger. Origines de l'alcalinisation et évolution des sols sous irrigation. Trav. Docum. Microf. Orstom, $\mathrm{n}^{\circ} 138,209 \mathrm{p}$.

Barbiéro L. and Berrier J., 1994. Mise en évidence d'une désalcalinisation naturelle de sols en milieu tropical - Transformation de sols alcalins en sols bruns subarides sur un bas fond Sahélien au Niger. C. R. Acad. Sci. Paris, t 319, série II, pp. 659-665.

Barbiéro L., Valles V. and Regeard A., 1995. Précipitation de la fluorine et contrôle géochimique du calcium dans des sols alcalins du Niger. Conséquences pour une estimation quantitative de l'évolution géochimique des sols. C.R. Acad. Sci., Paris, t 321, série II, pp. 1147-1154.

Bertrand R., N'Diaye M.K. and Keita B., 1994. L'alcalinisation/sodisation, un danger pour les périmètres irrigués sahéliens. Sècheresse ${ }^{\circ} 3$, vol. 5: 161-171.

Bertrand R., Keita B. and N'Diaye M.K., 1993. La dégradation des sols des périmètres irrigués des grandes vallées sud sahariennes (Cas de l'Office du Niger au Mali). Cahiers Agriculture, 2: 318329.

Bouzigue R., Favrot J.C., Herrera J. and CID G., 1992. Valeur diagnostique des caractères hydromorphes de vertisols de la vallée du Cauto à Cuba. Application à l'évaluation des besoins en drainage agricole. Cah. Orstom, Ser. Pédol., vol. XXVII, n²: 297-313. 
Bozza J.L. and Boyer G., 1988. Mise en valeur hydro-agricole des terrasses du fleuve Niger. Bilan des deux premières années d'expérimentation-développement, Septembre 1985-Novembre 1987. Rapport O.N.A.H.A./F.A.C., 30 p.

Brewer R. ,1976. Fabric and mineral analysis of soils. R.E. Krieger, Huntington New York. Charlot G., 1961. Dosage colorimétrique des éléments minéraux. Principes et méthodes, 2ème édit., 369 p., Masson, Paris.

Chauvel A., 1966. Carte pédologique du Sénégal Oriental au 1:200 000. Feuille de Kedougou et Kossanto-Kenieba, ORSTOM Dakar.

Chernet T. and TRAVI Y., 1993. Preliminary observations concerning the genesis of hight fluoride contents in the Ethiopian Rift. in Thorweihe U and Schandelmeier H - Geoscientific Research oin the Northeast Africa. Balkema, Rotterdam, pp. 651-655.

Choudhri M.B., 1972. Calcareous soils in West Pakistan. FAO/UNDP Regional Seminar on reclamation and management of calcareous soils, Cairo.

Delmas A.B., Berrier J. and Chamayou H., 1987. Corrosion patterns of the calcite: typology and evolutive sequences. in Feodoroff N., Bresson L.M. and Courty M.A., éd., Micromorphologie des sols - Soil micromorphology, pp. 303 - 308.

Desconnet J.C., 1994. Typologie et caractérisation hydrologique des systèmes endoréiques en milieu sahélien (Niger Degré carré de Niamey) Ph.D. thesis USTL Montpellier II, 310 p.

FAO, ISRIC AND ISSS, 1994. Draft World Reference Base for Soil Ressources, Wageningen/Rome. $161 \mathrm{p}$.

Fritsch E., Peterschmitt E. and Herbillon A., 1992. A structural approach to the regolith. Identification of structures, analysis of structural relationships and interpretation. Sci. Géol. Bull., 45: 77-97.

GaC J.Y., Droubi A., Fritz B. and Tardy Y., 1977. Geochemical behaviour of silica and magnesium during the evaporation of waters in Chad. Chemical geology, 19: 215-228.

Gavaud M., 1977. Les grands traits de la pédogenèse au Niger méridional. Travaux et Documents Orstom, $\mathrm{n}^{\circ} 76,102 \mathrm{p}$.

Gueddari M., 1984. Géochimie et thermodynamique des évaporites continentales. Etude du lac Natron en TANZANIE et du Chott el Jerid en TUNISIE. Mémoire des Sciences Géologiques $\mathrm{n}^{\circ} .76,143$

p.

Guero Y., 1987. Organisation et propriétés fonctionnelles des sols de la vallée du moyen Niger. Ph.D. thesis, Niamey/Tunis, 233 p.

Gran G. 1952. Determination of the equivalence point in potentiometric titrations. Part II. Analyst, 77: 661-671.

Griffiths J.F., 1972. Climates of Africa. World survey of climatology, vol. 10, Elsevier publish. Comp., Amsterdam, 599 p.

I.G.N., 1975. Couverture aérienne verticale, 1975 - NIG 40/600, photos 2474 et 2475, SAG II 2039 88,58 .

Jacks G. and Sharma V.P., 1995. Geochemistry of calcic horizons in relation of hillslope processes, Southern India. Geoderma, 67, 203-214.

Maignien R., 1965. Notice explicative de la carte pédologique du Sénégal au 1:1 000 000. 63 p. + Carte, centre ORSTOM de DAKAR-HANN.

Marlet S., Valles V. and Barbiéro L., 1996. Field study and simulation of geochemical mechanisms of soil alkalinisation in the sahelian zone of Niger. Arid Soil Research and Rehabilitation. 10: 243256.

N'Diaye M.K., 1987. Evaluation de la fertilité des sols de l'Office du Niger (Mali). Contribution à la recherche des causes et origines de la dégradation des sols dans le Kouroumari. Ph.D. thesis INP Toulouse, $133 \mathrm{p}$.

Shainberg I. and Letey J., 1984. Response of soils to sodic and saline conditions. Higardia, vol. 52 (2), $53 \mathrm{p}$. 
Sumner M.E., 1993 “ Sodic soils ”, new perspectives. Australian Journal of Soil Research, 31: 683750.

Valet S., 1995. Approche statistique et prédiction du comportement et du fonctionnement hydrique des sols. Application aux sols hétérogènes de la vallée du Niger. Ph.D. thesis Poitiers, 154 p.

Valles V. and Bourgeat F., 1988. Geochemical determination of the gypsum requirement of cultivated sodic soils I Development of the thermodynamic model "gypsol" simulating the irrigation water-soil chemical interactions. Arid Soil Research and Rehabilitation, vol. 2: 165-177.

Valles V., Bertrand R., Bourgeat F. and N'Diaye M.K., 1989a. Utilisation du concept d'alcalinité résiduelle généralisée pour apprécier la qualité des eaux d'irrigation et l'opportunité de certains amendements pour les sols sodiques. Application aux sols de l'Office du Niger (Mali) et de la vallée de l'Oued Medjerdah (Tunisie). Agronomie Tropicale., 44: 157-163.

Valles V., N'Diaye M.K., Bernadac A. and TARDY Y., 1989b. Geochemistry of water in the Kouroumari region, Mali. Al, $\mathrm{Si}$ and $\mathrm{Mg}$ in water concentrated by evaporation: development of a model. Arid Soil Research, vol. 3: 21-39.

Valles V., Pachepsky Y.A. and Ponizovsky A.A., 1991. Invariant criteria for irrigation water quality assesment in arid and semi arid regions. in Genesis and control of fertility of salt affected soils. ISSS Subcommission on salt affected soils Science, USSR, V.V. DOKUCHAEV Soil Institute, Moscow. pp. 330-333.

Valles V. and De Cockeborne A.M., 1992. Elaboration d'un logiciel de géochimie appliqué à l'étude de la qualité des eaux. Colloque "altération et restauration de la qualité des eaux continentales", Port Leucate, 1 et 2 Oct. 1992, pp.27-30.

Fig. 1 - Location of the study site.

Fig. 2 - pH survey of the 15 ha and concentric distribution of the soils in the studied zone.

Fig. 3 - Distribution of the horizons close to the contact zone: alkali soils/brown steppe soils.

1 Weathered layer with parent-rock structure; 2 Calcareous weathered horizon; 3 Grey sandy clay loam horizon; 4 Brown sandy clay loam horizon; 5 Superficial sandy horizon; + Chemical analysis sampling points ; Thin sections.

Fig. 4 - Distribution of the macro structure (main cracks) close to the contact zone: alkali soils/brown steppe soils.

Fig. 5 - Morphology of the calcareous nodules: a: Alkali soil, b: brown steppe soil, c: transition zone ( 1 white indurated cortex, 2 grey calcareous (with Quartz) matrix, 3 soft calcareous powder).

Fig. 6 - Spatial distribution of the chemistry close to the contact zone: alkali soils/brown steppe soils (meq/l on the saturated paste extract).

Fig. 7 - Concentration diagrams.

Fig. 8 - Distribution of the Total Dissolved Substances values close to the contact zone: alkali soils/brown steppe soils (meq/l on the saturated paste extract).

Fig. 9 - The gap of 1 meter between the morphological (A) and the geochemical (B) transition.

Fig. 10 - Saturation with respect to fluorite of paste extracts from alkali soils and brown steppe soils

Fig. 11 - Hypothetic model of alkali soil and brown steppe soil genesis under the former pond (A: Brown soil with abrupt structural change, alkaline in depth - B: non-alkaline brown steppe soil - C: non-saline alkali soil - 1: dune or sandy bank - 2: crystaline bedrock - 3: alkaline horizons - 4 and 5: high and low level of the former pond. 6: infiltration and soil leaching - 7: evaporation.

Phot. 1 - precipitation forms of calcite in the nodules of alkali soils.

Phot. 2 - precipitation forms of calcite in the nodules of brown steppe soils.

Phot. 3 - precipitation forms of calcite in the nodules close to the contact zone.

Phot. 4 - aerial picture of "Lossa" catchment and indices of a former pond in the valley bottom.

Table I - Chemistry of the runoff waters. 


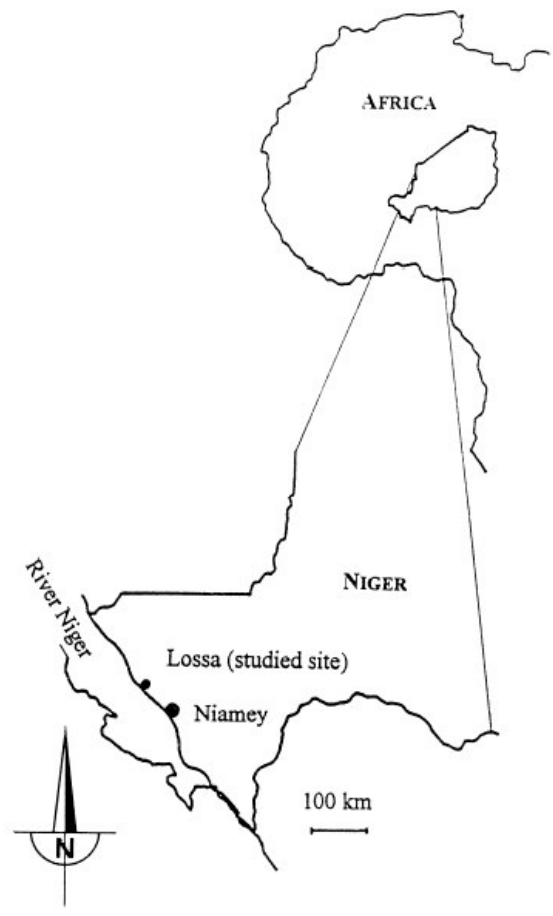

Fig. 1. Location of the study site.

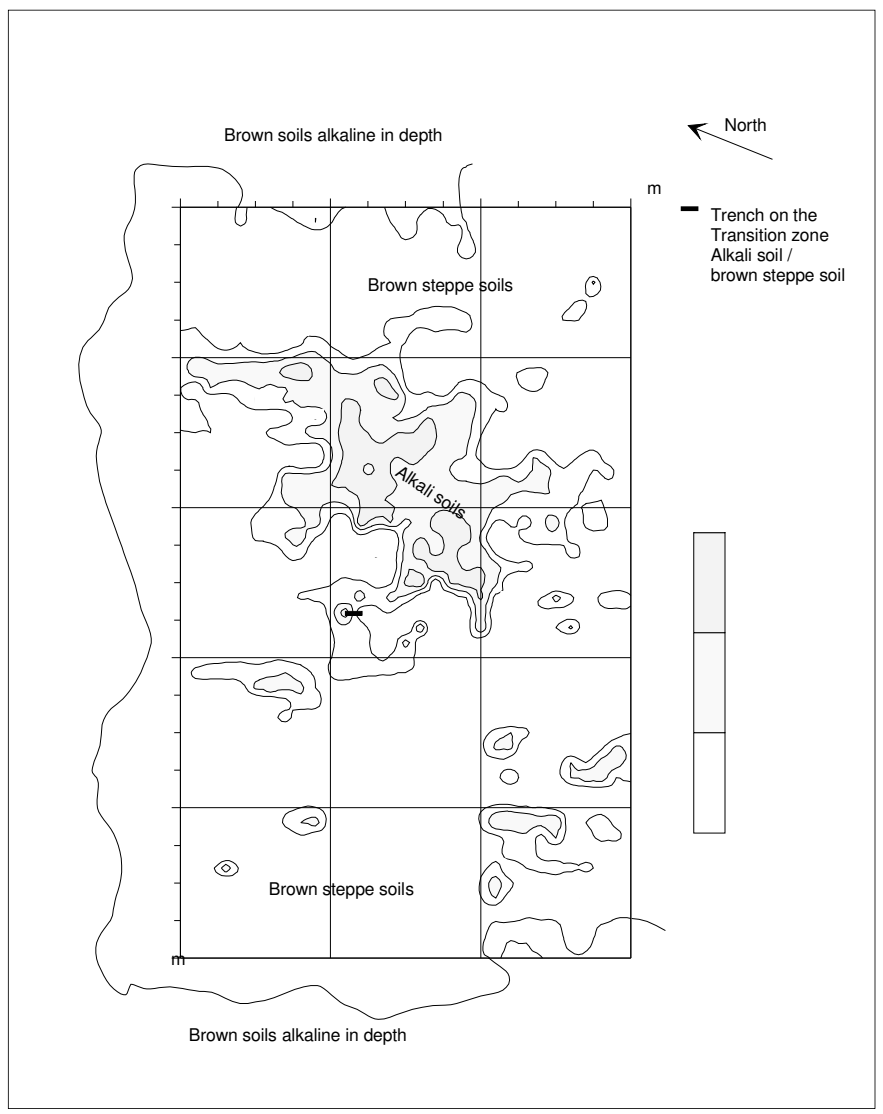



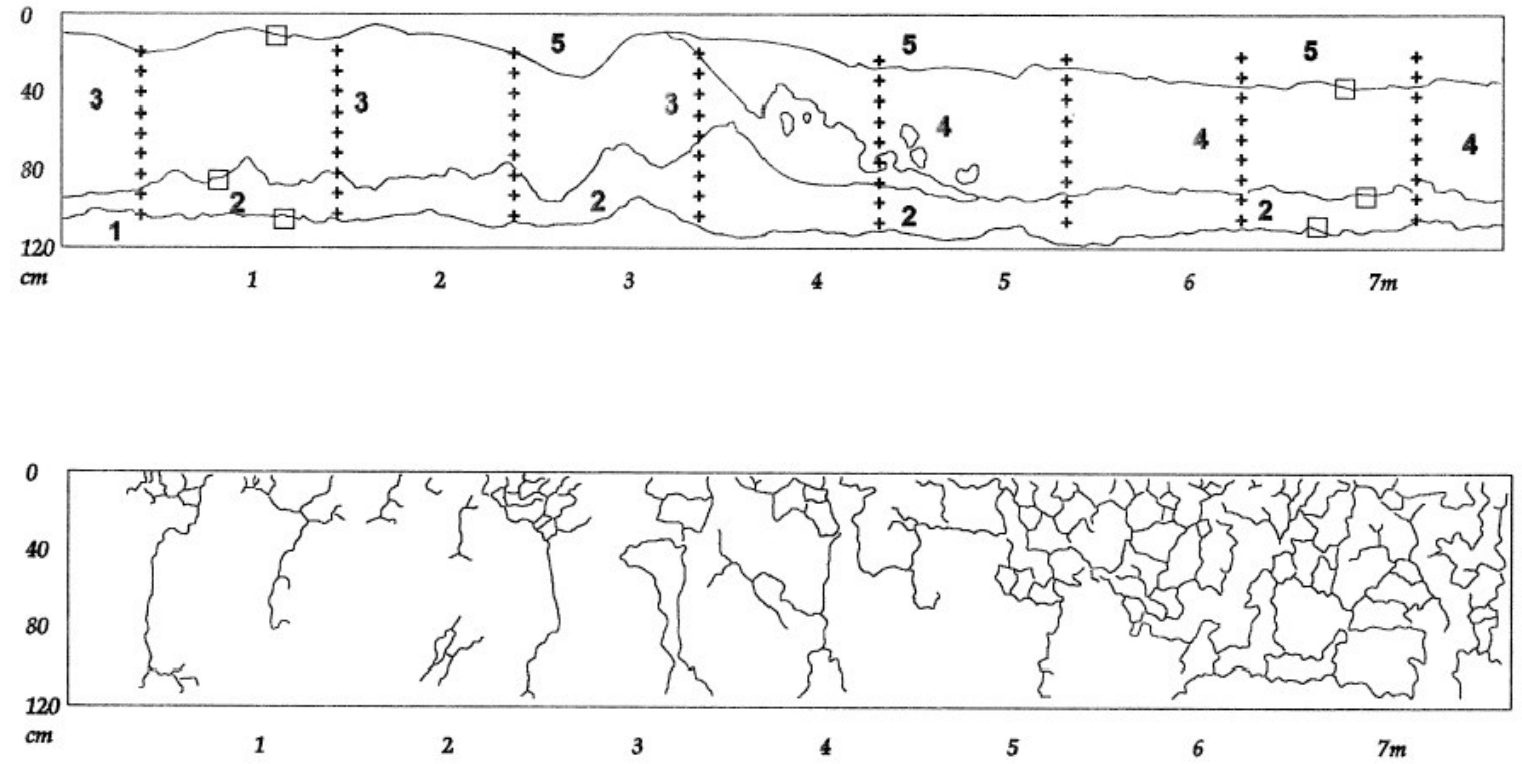

(a)

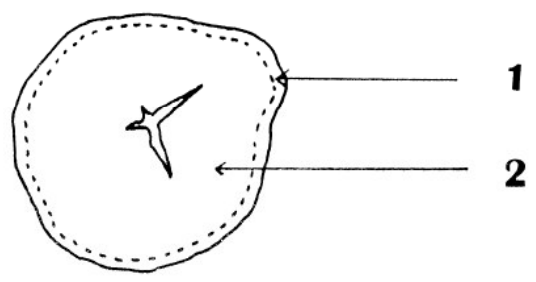

(b)

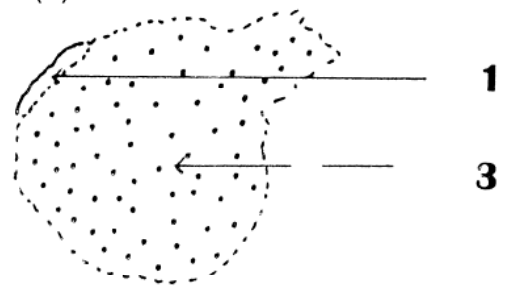

(c)

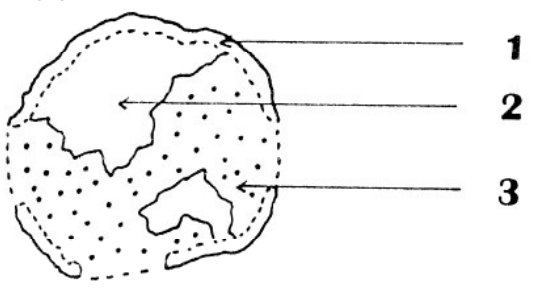



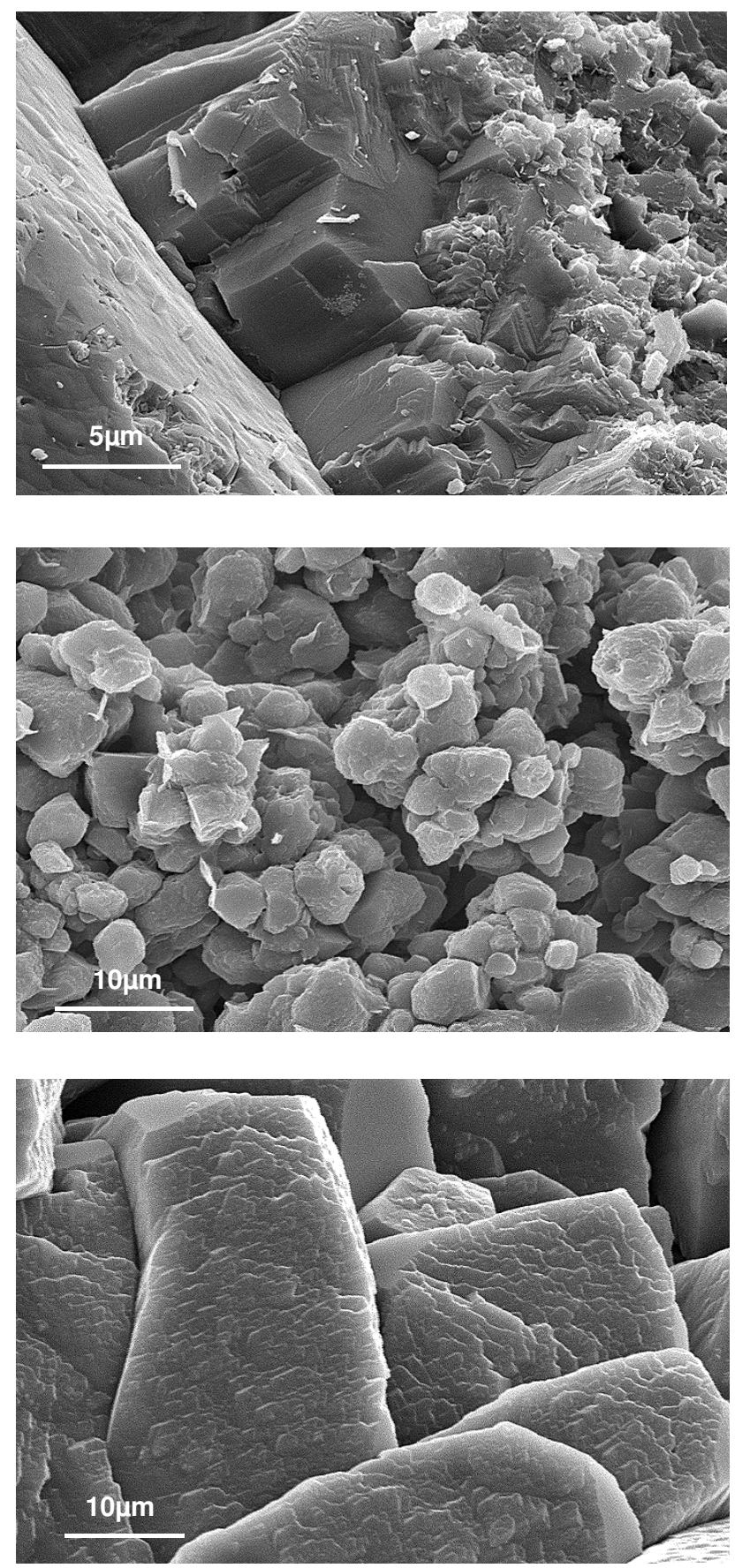

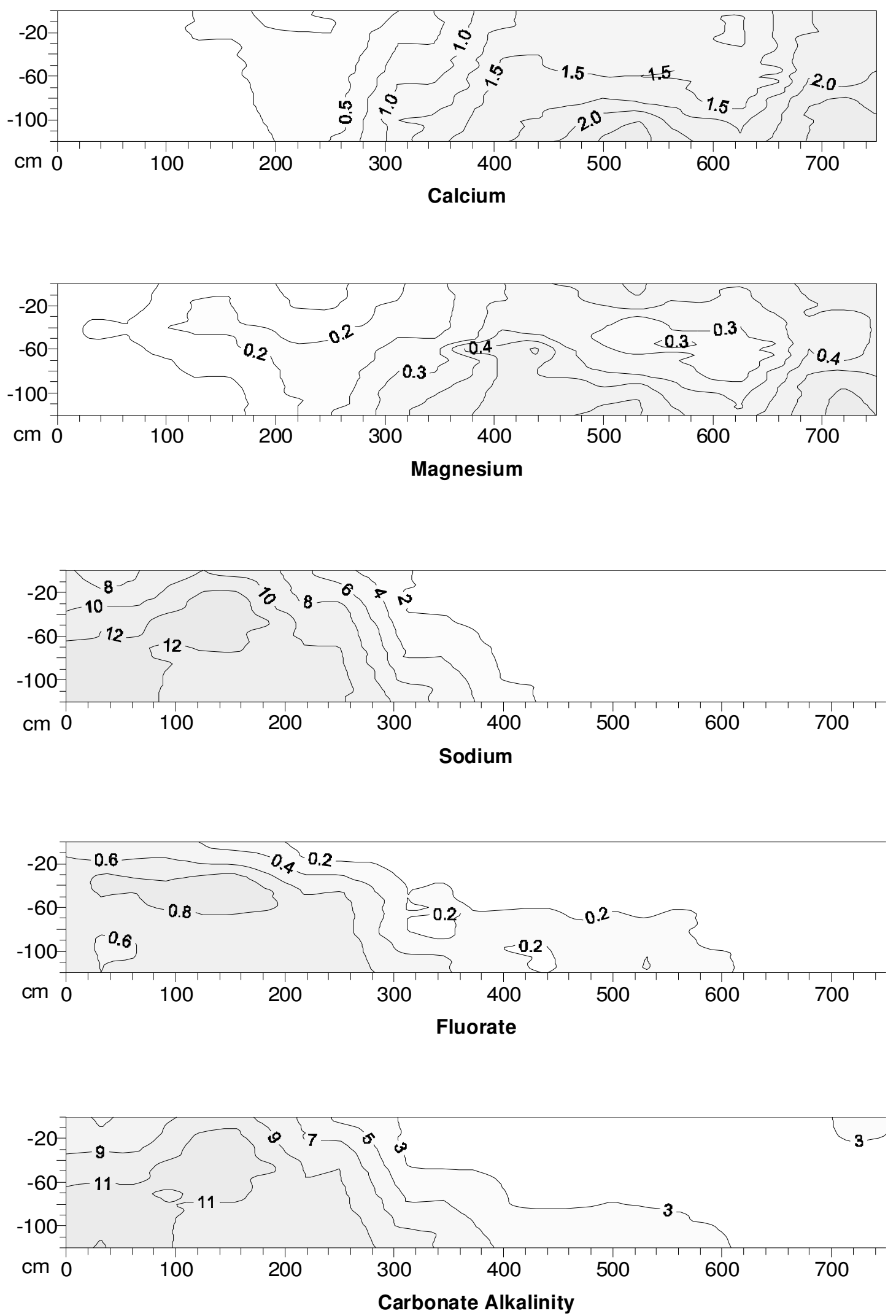

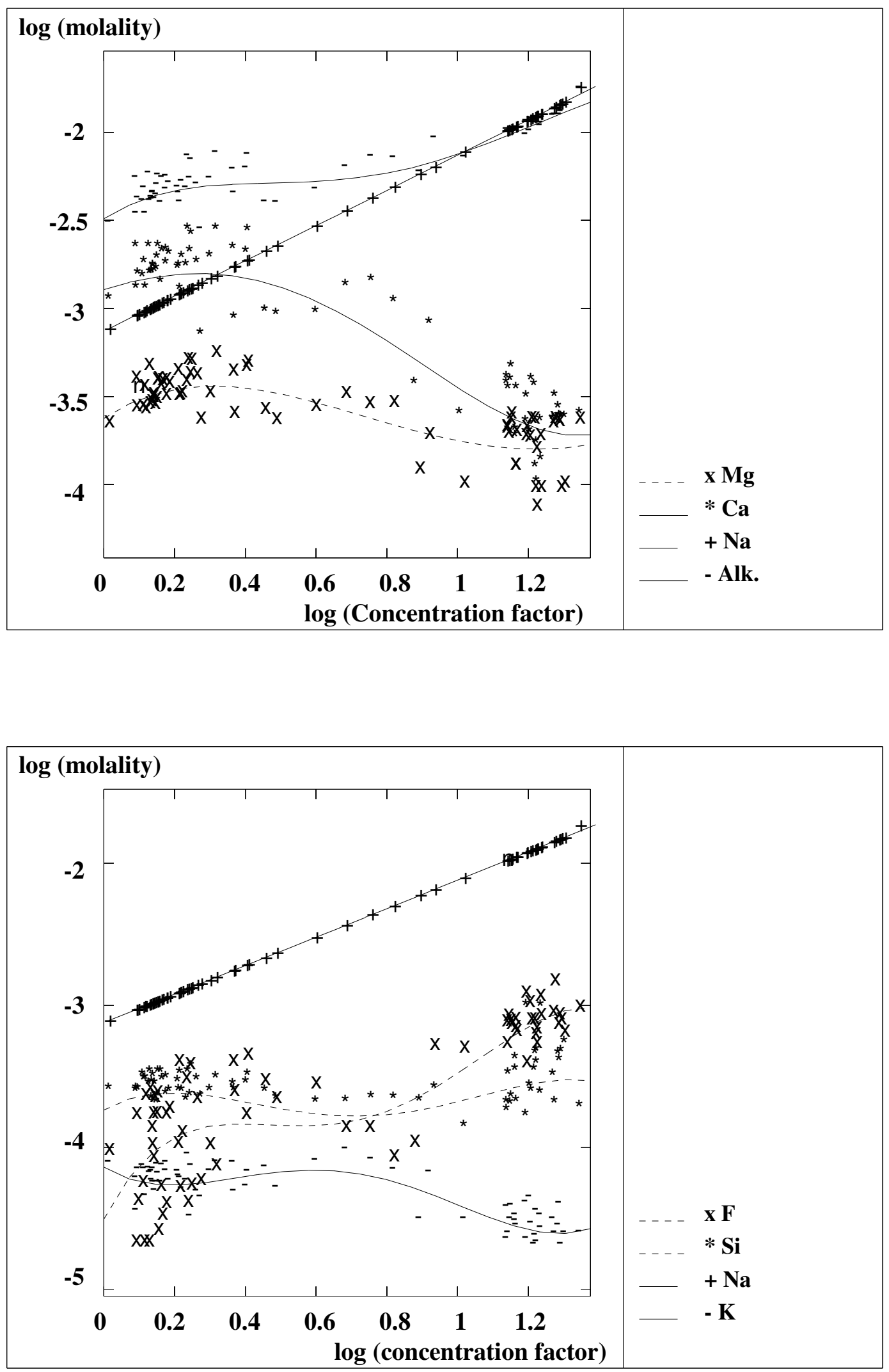

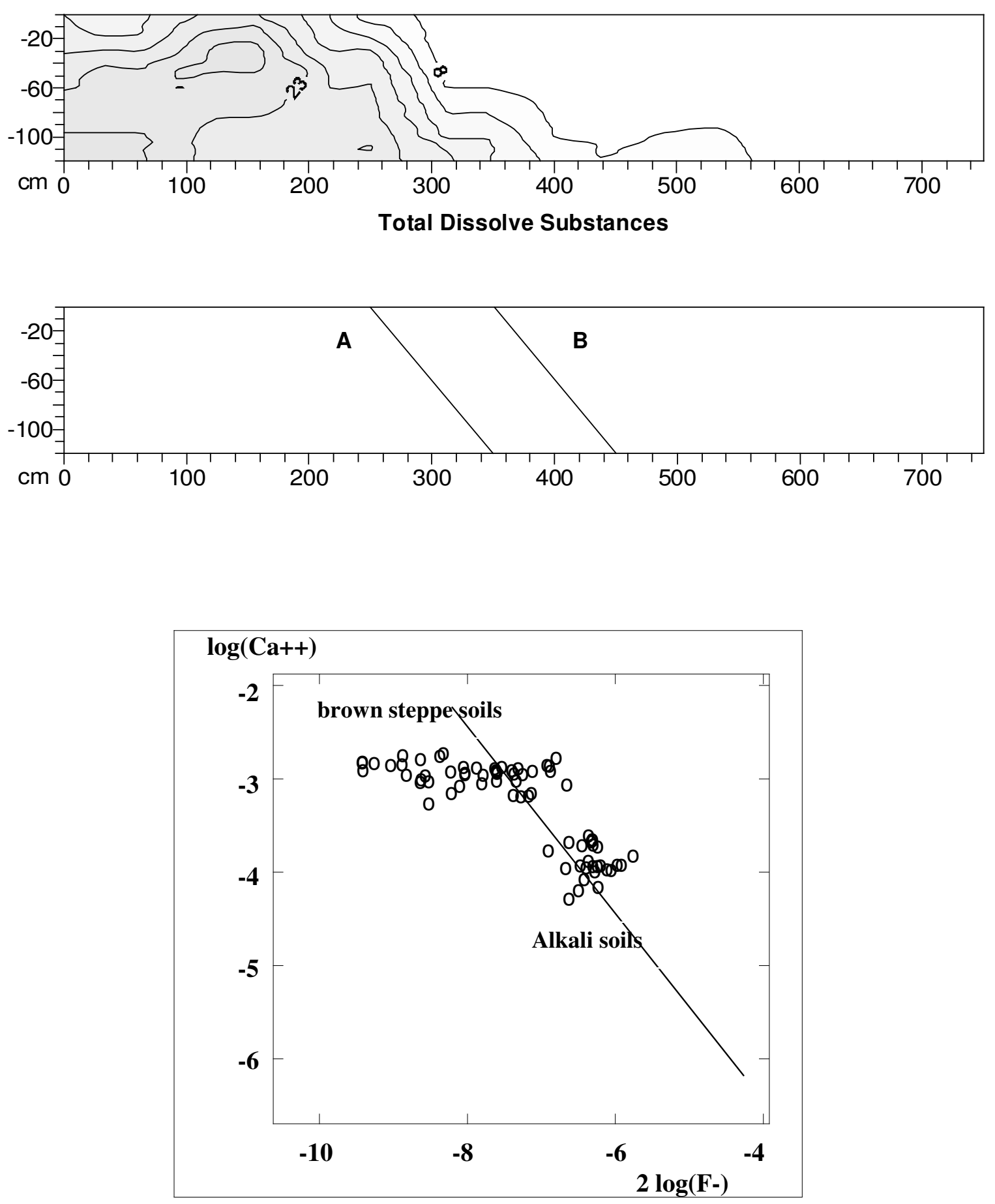


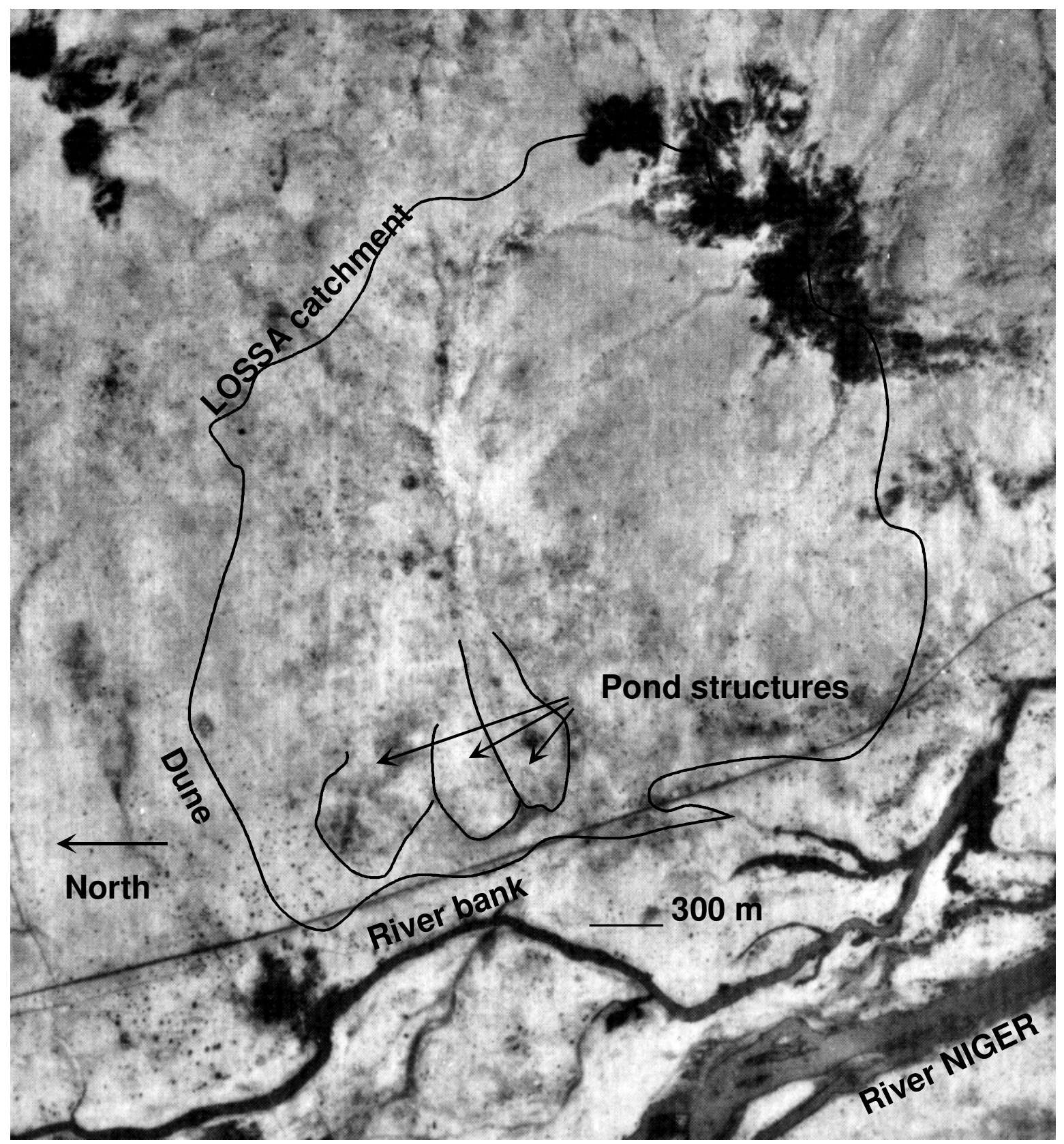



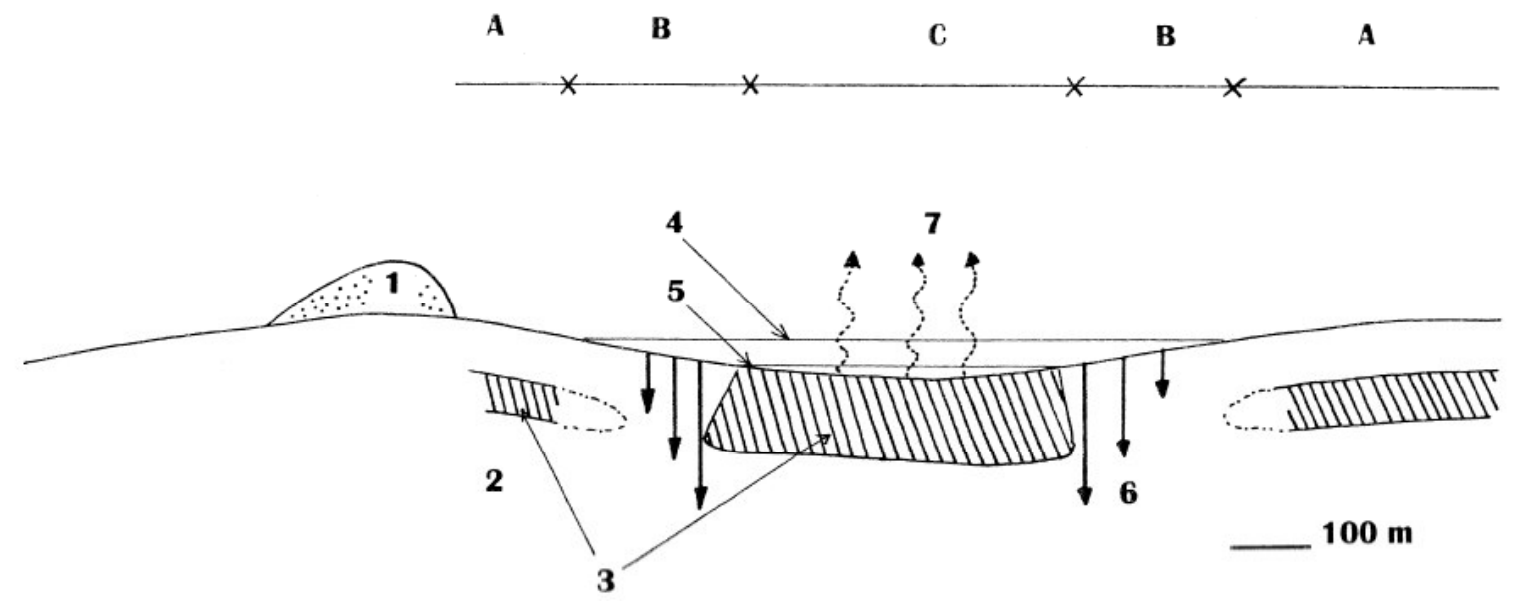

\begin{tabular}{cccccccccc}
\hline $\begin{array}{c}\text { sample } \\
(\mathbf{m m o l} / \mathbf{l})\end{array}$ & $\mathbf{N a}$ & $\mathbf{K}$ & $\mathbf{C a}$ & $\mathbf{M g}$ & $\mathbf{C l}$ & $\mathbf{S O 4}$ & $\mathbf{F}$ & $\mathbf{N O 3}$ & Alk. \\
\hline $\mathbf{1}$ & 0.060 & 1.987 & 0.026 & 0.016 & 0.092 & 0.036 & 0.171 & 0.319 & 1.145 \\
$\mathbf{2}$ & 0.098 & 0.448 & 0.029 & 0.015 & 0.061 & 0.021 & 0.026 & 0.021 & 0.420 \\
$\mathbf{3}$ & 0.266 & 0.330 & 0.174 & 0.108 & 0.092 & 0.052 & 0.029 & 0.079 & 0.883 \\
$\mathbf{4}$ & 0.273 & 1.403 & 0.273 & 0.108 & 0.307 & 0.072 & 0.045 & 0.257 & 1.660 \\
\hline
\end{tabular}

